plasma bilirubin level and the risk of kernikterus. Many influences, e.g. the plasma albumin level, the administration of drugs, dehydration, hypoglycaemia, the state of nutrition and the relative maturity, may all be concerned. It is difficult to evaluate the importance of each, and as yet it is not known why, under similar circumstances, one animal may succumb yet another remain unaffected.

All actively concerned in the study of neonatal jaundice will find this book stimulating and of immense value for not only does 'Kernicterus' deal with most aspects of the subject, but it indicates the way in which future research might be directed.

On the other hand paediatricians concerned primarily with the day-to-day clinical care of children will find the content of theoretical rather than of practical value and will probably consider the price of $68 \mathrm{~s}$. too high.

Antibiotics and Sulphonamides in Paediatrics. By JOSEPH Ungar and LeONARD HAas. (Oxford Antibiotics Monographs.) (Pp. vii $+149 ; 6$ tables. 15s.) London: Oxford University Press. 1962.

This comprehensive little book should find a place in the pocket of every doctor who undertakes the care of infants and children. It should be made compulsory for paediatric housemen. While it is essentially practical, the basic principles necessary for the intelligent use of antibiotics are clearly set out.

It is divided into three parts. The first, a brief introduction, deals with general aspects such as the development of bacterial resistance and the use of drug combinations. The middle section is packed with useful information covering all the preparations of value in current use. Taking them singly or in groups, it describes their properties. Stability, toxic effects, atsorption and excretion are covered, and are followed by advice on methods of administration and dosage.

The final section is the most controversial. It deals with the management of paediatric infections grouped under anatomical systems. The advice is sound and up to date and contains a brief section on the newborn infant. Some might disagree with the daily use of intrathecal streptomycin in Esch. coli meningitis of the newborn, but little else was found with which to quarrel. It is remarkable to find so much of value, so clearly printed in such a small book.

Vaccins et Sérums. By P. Chassagne. (Pp. 404. NF. 60.) Paris: Doin and Cie. 1961.

This monograph by Professor Chassagne is another in the series 'Bibliothèque de Thérapeutique Médicale' under the direction of Professor Raymond Turpin. After a rather cursory first part, dealing with immunity in general, the main (second) part describes in detail the various immunological procedures in use in France. The third (and last) part contains useful information on the principal regulations about vaccination in France and a lengthy tabulation of the obligatory and recommended vaccination procedures in most other countries in the world (based on the latest W.H.O. recommendations).
British readers will find the French views on immunization most interesting, if only for comparison with British and American ideas, but there are some omissions which are unexpected even in a French book, e.g. A. T. Glenny's work on primary and secondary stimuli and other principles of immunization, and also Pearl Kendrick's outstanding contributions to the preparation and assay of pertussis vaccine. At a time when the trend in Britain is to reduce the volumes of vaccines to $0.5 \mathrm{ml}$., it is surprising to find that the recommended second dose of cholera vaccine for an adult is $2 \mathrm{ml}$., and that the third dose of diphtheria toxoid for a child under the age of 18 months is also $2 \mathrm{ml}$. There are good accounts of vaccination procedures against tuberculosis, poliomyelitis and rabies, but it is disconcerting to meet descriptions of dysentery bacteriophage (the results being 'sometimes brilliant') and meningococcal vaccine.

The book contains some interesting statistics: for example, there were 3,167 deaths from diphtheria in France in 1945 , but only 31 in 1960 . In the chapter on tetanus, it is stated that there were 80 cases in the non-vaccinated German Army in Normandy, and 'numerous cases' in the non-vaccinated Japanese Army. The non-vaccinated civilians in the liberation of Manilla in the Philippines had no fewer than 400 cases of tetanus.

A major defect, which could perhaps be remedied in subsequent editions, is the lack of references: there is little point in quoting names (and even dates) without providing the means of referring to the original papers or books.

This paper-covered book of 404 pages costs $60 \mathrm{NF}$. As a useful reference book it should be found in all British medical libraries.

\section{A Ciba Foundation Symposium on Somatic Stability in the} Newly Born. (Editors for the Ciba Foundation: G. E. W. Wolstenholme and Maeve O'Connor.) (Pp. xii + 393; 63 figures. 50s.) London: Churchill. 1961.

Published proceedings of symposia are of great value to the participants as a permanent record of their deliberations. However, with the growing number of congresses and symposia there should be other good reasons for their publication. In the first place the work reported should be recent, of high quality and better presented as part of a symposium than as an article in a journal. The discussions should be authoritative and stimulating and there should be a theme uniting the original communications and discussions. Finally, publication should be neither so hurried as to give no time for second thoughts nor so delayed that the data has been published elsewhere or superseded. On all these counts it is possible to welcome the publication in book form of this symposium held at the Ciba Foundation in January 1961.

The theme is stated explicitly in the title and the 30 participants, although drawn from many disciplines, were united in considering the stabilizing and adaptive mechanisms which are present to safeguard the transition from intrauterine life to more or less independent existence. The viewpoint is essentially biological and the experimental approach receives the greatest emphasis. 